\title{
Educational Institutions' Contribution to Lean Engineering
}

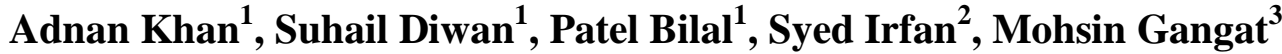 \\ ${ }^{I}$ Assist. Professor, Electrical Engineering Dept. JIEMS Akkalkuwa, ${ }^{2}$ Assist. Professor, Mechanical Engineering \\ Dept. JIEMS Akkalkuwa, ${ }^{3}$ Assist. Professor, E\&Tc Engineering Dept. JIEMS Akkalkuwa
}

\begin{abstract}
Lean engineering is a methodology on minimizing 'waste' within manufacturing system while simultaneously maximizing productivity. Engineering institute have massive infrastructure with hi-tech laboratories with well-equipped instruments and tools. These educational institutes work on hourly basis, generally 7-8 hours. On the contrary particular lab or instrument used once a week as scheduled by departmental timetable at the time of practical. Other than those 4-6 hours of practical those instruments or tools remain, idle.
\end{abstract}

Keywords- ASD-Automatic Sanitizer Dispenser, IWHInstant Water Heater

\section{I - INTRODUCTION}

$\mathbf{L}$ ean engineering is a holistic approach to engineering that influences:

- Leadership principles and practices within engineering organizations

- Team structures

- Team processes and process visualization

- Tools and technologies used to optimize for efficiency

- Management and creation of engineering intelligence
Lean engineering practices aim to eliminate waste while creating more value for the customer. In manufacturing, where products move from one step to the next until they are completed, it's easy to see where waste is created: You just have to look for physical evidence of bottlenecks, blockers, etc. But what is waste in engineering, where the majority of the "product" is inside the minds of employees? Waste, in Lean engineering, is defined as various activity, process, or product that does not add value to the customer.

In this competitive world, where we are continuously focusing on efficiency, accuracy. These idle instruments/tools is a bone of content. It is something that we should worry. Instruments are efficient and smooth in working when frequently used. Idle instruments results in wear and tear plus reduced efficiency. In this paper, we are focusing on utilizing these instruments other than academic purpose on a greater scale. Consequently it will results in added instrument value, creativity, increased productivity. Ever wonder if lean engineering will work for you? Ask yourself these questions to help you assess whether or not lean engineering will work for you.

- Does your company's engineering intelligence go out every single day at around 5 to $6 \mathrm{pm}$ ?

- Does your output level impact the production output level of your enterprise? 


\section{International Journal of Innovations in Engineering and Science, www.ijies.net}

- Does the quality of engineering get output delayed by due dates and workload?

- Does the adoption of brand new design technology hinder processes that are beyond engineering's control?

The initial step in the lean engineering process is to obtain an honest assessment of the present condition within the department. This includes defining engineering's role within the enterprise, zeroing in on the resources as well as the dynamics that make up the whole of engineering.

\section{II - METHODOLOGY}

As a test subject, we in this institute took up electrical workshop for manufacturing

1. Automatic sanitizer dispenser

2. Instant water heater

3. Energy audit

Automatic Sanitizer dispenser

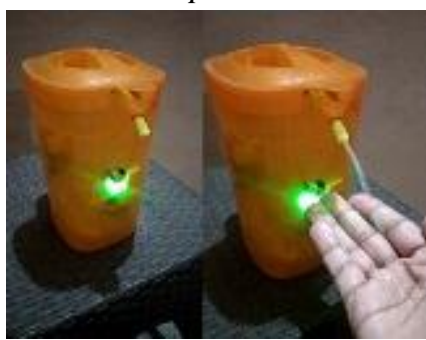

Fig.1- ASD Automatic Sanitizer Dispenser

The Fig. 1 shows automatic hand sanitizer. During pandemic sanitizer was need of hour. Things were very vulnerable specially at public places where frequent touches may cause outburst in disease. Conventional hand sanitizers need to be operated manually. We tried to design a circuit with proximity sensors and IR module that can be able to dispense small amount of sanitizer when we bring hand closer to container. It results in avoiding multiple touches and contamination. The circuit diagram is shown in Fig. 2

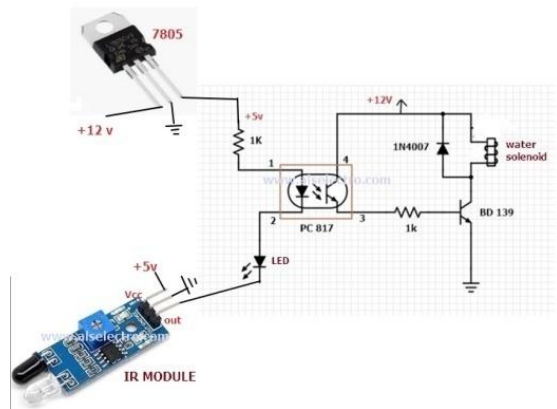

Fig.2 Circuit diagram of ASD

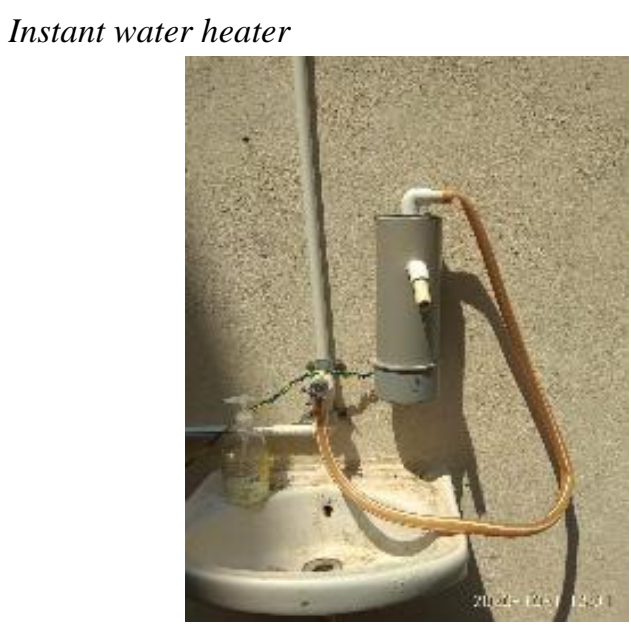

Fig.3- IWH Instant Water Heater

Fig. 3 shows Instant water heater. This heater were created from wastes. Wastes from college such as PVC pipes, caps, thermostats and heating coils. Some of the features of this instant water heater are as follows,

- Instant hot water within $10 \mathrm{sec}$

- Shockproof

- Simple and robust design

- Easy for installation and repair

- Cheap and affordable

Some of the technical details of this IWT are as follows Table 1

\begin{tabular}{|l|l|}
\hline Rating & $3000 \mathrm{~W}$ \\
\hline Supply & $1 \phi, 230 \mathrm{~V}, 50 \mathrm{~Hz}$ \\
\hline Thermostat & $20 \mathrm{~A}, 6$ " inch \\
\hline Capacity & 3 Liters \\
\hline
\end{tabular}

\section{Energy Audit}

Said engineering college is situated in a huge campus where various other schools, colleges and institutes are there. We electrical department made various audit teams for conducting energy audit. This energy audit consisted on preliminary survey, report making and finally implementations. The purpose of audit was to reduce the consumption of electrical energy and reduce bill. Replace outdated equipments and appliances with efficient ones.

There are generally three phases to an Energy Audit, depending on the complexity and detail required by the client:

1. Investigation Phase

2. Monitoring Phase 


\section{International Journal of Innovations in Engineering and Science, www.ijies.net}

\begin{abstract}
3. Analysis \& Reporting Phase

\section{Type 1 Basic Energy Audit}

Type 1 / Level 1 audits provide a quantitative overview that is typically suitable for smaller sites with lower energy expenditures, or as a scoping audit for larger sites. Type 1 defines the minimum level of detail for an audit required to comply with the Standard.

Type 1 / Level 1 audits provide a quantitative overview of energy performance and identify low cost and no-cost opportunities with payback periods of up to 2 years. The accuracy of costs and benefits would generally only be sufficient for low cost operational expenditures or as a method for prioritising opportunities for more detailed assessment.
\end{abstract}

\section{Type 2 Detailed Energy Audit}

Type 2 / Level 2 audits provide detailed analysis of energy performance to quantify the full range of opportunities for a site. Type 2 defines a detailed level of audit involving a comprehensive review and analysis of equipment, systems, and operational characteristics of the whole building to enable quantifiable energy savings recommendations.

Type 2 / Level 2 audits are required to include financial analysis of recommended energy performance improvement actions, using estimates that are of sufficient accuracy for operational expenditures or medium-scale capital investments.

\section{Type 3 Precision Subsystem Audit}

Type 3 / Level 3 audits are detailed audits of specific subsystems, with additional data gathering and measurement to provide a higher level of accuracy. Audits of this type are typically focussed on a process or subsystem level, such as for HVAC, building management systems, compressed air or lighting, rather than a whole site. Type 3 / Level 3 audits involve onsite measurements to monitor energy data over a period long enough to capture the various operating conditions and relevant variables, in order to be able to quantify costs and benefits to a level sufficient to meet the site's capital expenditure process requirements. Type $3 /$ Level 3 Audits of Industrial and related operations are often referred to as 'Investment Grade' audits in that context.

\section{III - CONCLUSION}

In this paper we briefly discussed about lean engineering, its aspect in educational institutes and future scope. Three test subjects are explained in detail, their construction, design, operation and characteristics lot can be done in this breakthrough path. Instant water heater can be designed in more efficient way similarly
Automatic hand dispenser is need of hour. With the help of energy audit in colleges and educational institutes wastage of power can be reduced and outdated loads and equipment can be replaced with new and efficient ones. By doing this efficiency reliability and accuracy of system can be increased to new level.

\section{ACKNOWLEDGEMENTS}

The authors are thankful to president JIIU's G. M. Vastanvi and Dr. Kamaluddin Sayyed, Principal, Jamia Institute of Engineering and Management Studies, Akkalkuwa Dist. Nandurbar for their encouragement and support.

\section{REFERENCES}

[1] Antony, J. (2015), "Editorial note for the special issue on "Lean Six Sigma for higher education"", International Journal of Quality \& Reliability Management, Vol. 32 No. 9.

[2] Cristina \&Surugiu Felicia, 2012. "Implementing Lean in higher education university," Constanta Maritime University Annals, Constanta Maritime University, vol. 18(2), pages 279-282.

[3] Höfer, S. (2016). Lean Sales: Steigerung des Wertschöpfungsanteils in Vertriebsprozessen. In: $H$. Künzel (ed.), Erfolgsfaktor Lean Management 2.0 (pp. 189-208). Heidelberg: Springer.

[4] J.P. Womack, D.T. Jones, and D. Ross, The Machine that Changed the World, Rawson Associates, New York, 1990, 323 PP, International Journal of Human Factors in Manufacturing

[5] Monden, Y. (1998). Toyota production system: An integrated approach to Just-In-Time. (3rd ed.). Norcross, GA: Inst of Industrial Engineers.

[6] Ohno, T. (2012). Taiichi Ohno's Workplace management: Special 100th birthday edition. (1st ed.). New York, NY: McGraw-Hill Education.

[7] Ohno, T., \& Bodek, N. (1988). Toyota Production System: Beyond Large-Scale Production. (1st. ed.). Cambridge, MA: Productivity Press.

[8] Stephan Höfer*, JörgNaeve** International Journal of Contemporary Management Volume 16 (2017) Number 4, pp. $\quad$ 63-80 doi:10.4467/24498939IJCM.17.038.8261 www.ejournals.eu/ijcm

[9] Waterbury, T. (2015). Learning from the Pioneers: A Multiple-case Analysis of Implementing Lean in Higher Education. International Journal of Quality \& Reliability Management, 32(9), 934-950.

[10] Wiegand, B., \& Franck, P. (2004). Lean Administration 1: So warden Geschäftsprozesse transparent. Aachen: Lean Management Institute.

[11] Womack, J.P., \& Jones, D.T. (1997). Auf dem Wegzumperfekten Unternehmen (Lean Thinking). Frankfurt: Campus. 